\title{
Financing the Urban Water Sector in the United States of America, with Possible Implementation in the Sultanate of Oman
}

\author{
Ghiyath Nakshbendi
}

University of Maryland University College

P O Box 608, Glen Echo, MD 20812, USA

\section{وسائل تمويل مشاريع المياه والمجاري في الولايات المتحدة الأمريكية وملائمة

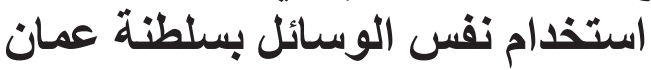$$
\text { غباث نقشبندي }
$$

الخلاصة: يتعرض العالم لتغيير ات في ملكية و إدارة قطاع المياه و المجاري. من ناحية نرى إن القطاع العام في الدول النامية يتجه

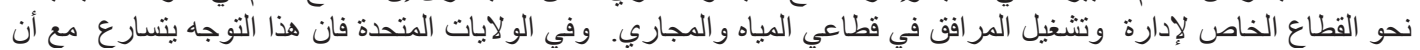

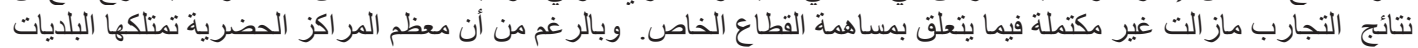

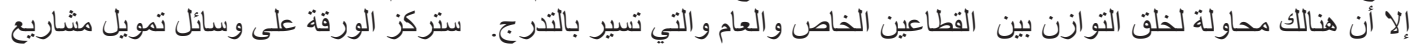

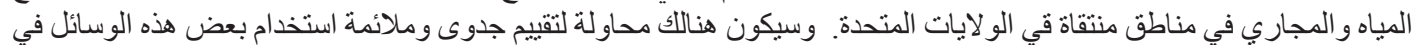
سلطنة عمان . هل تر غب الأسو اق المالية في مجلس التعاون الخليجي في المساعدة في التمويل؟ هنئ

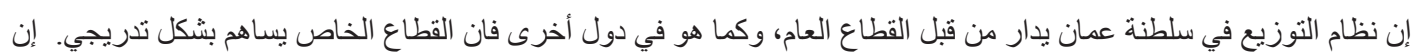

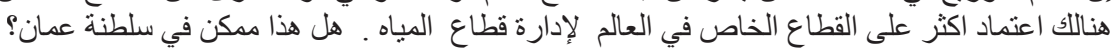
يعتمد أسلوب البحث على تحليل المعلومات المتو افرة وعلى خبرة الباحث في المجال المالي. المصطلحات الرئيسية: الأسواق المالية، التمويل، دول مجلس التعاون الخليجي، عمان ، المياه ، المجاري
\end{abstract}

\begin{abstract}
The world has been experiencing a change in water and sewage infrastructure ownership and management. At one end, the public sector in developing countries has been moving towards engaging the private sector in the management and operation of water and sewage sectors. In the United States, the trend is catching up, even though there has been a mixed experience in the involvement of the private sector. While most urban facilities are owned by the public entities of the concerned urban centers, striking up a balanced involvement of both sectors is gradually taking shape. The paper focuses on financing urban water and sewage sectors in selected areas of the United States. An attempt is made to assess the viability and suitability of utilizing some of these methods in the Sultanate of Oman. The distribution system in the Sultanate of Oman is managed by the public sector; like in other countries, the private sector is getting involved on a gradual basis. There is more reliance on the private sector to manage the water sector worldwide. Can this happen in the Sultanate of Oman? The method will rely on analysis of the available data and the researcher's work experience in the financial sector.
\end{abstract}

Keywords: Bonds, capital markets, financing, GCC, Oman, sewage, water. 


\section{Introduction}

The world is experiencing an increase in population and a decrease in the availability of safe drinking water. A recent objective of the world community was "To halve, by the year 2015, the proportion of the world's people whose income is less than one dollar a day and the proportion of people who suffer from hunger and, by the same date, to halve the proportion of people who are unable to reach or to afford safe drinking water" (United Nations, 2005). There is an increasing need worldwide for new water infrastructure and upgrading and rehabilitating of existing infrastructure. The world is experiencing a need for rehabilitating its aging infrastructure. In the United States of America alone, by one estimate there will be a " $\$ 300$ - $\$ 800$ billion funding gap over the next 20 years to repair aging infrastructure at the nation's 16,000 wastewater treatment and 40,000 drinking water facilities" (Eichenscher, 2005).

Other countries are facing similar problems. Current spending on new water infrastructure in developing and emerging countries is roughly $\$ 80$ billion a year. This will have to more than double over the next 20-25 years, to around $\$ 180$ billion. Much of the increase will be for household sanitation, wastewater treatment, treatment of industrial effluents, irrigation and multipurpose schemes- (Camdessus, 2005). Most water provider companies in the world are public utilities. These utilities are subjected to the typical process of budgeting and bureaucratic procedures which add cost and time to reach resolution.

Identifying methods to finance water projects deserves more attention than has been given so far. In this paper an attempt will be made to identify some methods of financing water utilities in the United States of America, with a view to assessing its applicability in the Sultanate of Oman. The results of such assessment might provide more ideas on the acceleration of the privatization process in the utilities sector in Oman.

In the U.S., “. . . utilities cannot count on federal funds financing infrastructure improvement projects. Therefore, there are rate increases, bond issues, capital reserves, streamlined operations, loans, grants and surcharges to fund needed water system improvements. Priorities for capital projects often vary by region" (Zeilig, 2005). The point to be made is that reliance on the federal government is not an option. Local water providers rely on their customer base for their operation and survival. Almost all of the utilities in the Middle Eastern countries, including Oman, are publicly owned and thus rely on government appropriation for program implementation.

Oman is well known for its resolve and desire to improve its economy and the living standards of its people. The advancement in all sectors of the economy in the last 30 years or so is phenomenal. A closer look at the growth of GDP, life expectancy, the electricity production and the increase in internet users demonstrates strong advancement. Its privatization efforts are continuing; a new law promulgated in 2004 removed limits on the share of foreign participation in privatized companies. The government divested a significant part of its shares in a petroleum company, and a second mobile telephone company was licensed in recent months (IMF, 2005).

The recent privatization initiative by the State in selling $30 \%$ of its stake in Omantel (Business and Industry, 2005) is another example of its determination to follow the steps taken by other countries in their drive to promote a market economy and encourage customer's reliance on their sources, thus reducing some government subsidies. Therefore, there is a need to develop a new method to finance water projects and to rely less on government funding by encouraging more involvement of the private sector.

\section{Financing the Urban Water Sector in the U.S.}

The U.S. was selected due to its large number of water and sewage facilities and the presence of diversified financing methods which could be considered as a guide to other countries. A major water utility in the country was selected to be studied. Its selection was based on the number of customers served and its budget. Also, examples from three other states will be presented.

\section{The Washington Suburban Sanitary Commission}

The Washington Suburban Sanitary Commission (WSSC) is a Maryland public entity which was established in 1918 as a regional organization. Currently, it provides water and sewer services to the 1.6 million residents (433,000 customer accounts) of Maryland's Montgomery and Prince George's Counties, which border Washington, D.C. It is one of the 10 largest water and sewer utilities in the country. It is governed by a board of commissioners who are 
appointed by their respective County Executives and confirmed by their County Councils. WSSC produces an average of 167.5 million gallons $\left(634,470 \mathrm{~m}^{3}\right)$ of water per day; its wastewater treatment is provided and operated by WSSC and one plant operated by The District of Columbia Water and Sewer Authority (WASA). The two counties, Montgomery and Prince George's, prepare ten-year water and sewer plans, which are updated annually (WSSC, 2006). WSSC is empowered to establish water consumption rates, sewer usage rates, connection charges, front foot benefit charges to repay funds borrowed by WSSC for water and/or sewer main construction. The front foot benefit charges assessment is determined by multiplying property footage by the rate per foot for the appropriate property classification. WSSC allows visitors to pay a fee for engaging in fishing from portions of the shorelines of reservoirs and recreational boating. Finally, WSSC can levy, if required, appropriate and valorem taxes (WSSC, 2006). This is very important to make the utility financially independent and capable of running its operations.

\section{WSSC's Annual Budget}

In order to determine its financing needs, an annual budget is prepared, noting that the utility is self sufficient and its customers pay for all the charges, including the capital programs. The annual budget consists of operating and capital budgets. Each budget includes water and sewer elements. Also, the operating budget includes an Interest and Sinking Fund, while the capital budget includes General Construction Bonds Fund. So, each type of operating fund is associated with a corresponding bond fund. The related operating funds are responsible for the payment of the funds that were used to finance its operation. This separation allows each service to be considered as a cost center.

\section{Financing Methods}

The Commission finances its operation mainly through the issuance of bonds. It issues Water Supply Bonds (Capital Fund) to finance capital activities dealing with the delivery of water to customers. In the meantime, money received from customers paying their water bills is used to pay for all expenses related to water delivery, including the repayment of principal and interest of loans accumulated in the Water Supply Bonds. The same mechanism is applied for the sewer side of the operation. i.e. there is a Sewage Disposal
Table 1. Operating budget - major expense category.

\begin{tabular}{lrr}
\hline & (\$ millions) & $\mathbf{( \% )}$ \\
\hline Salaries and wages & 78,835 & 16.0 \\
Utilities & 16,677 & 3.4 \\
Regional $\quad$ sewage & 36,060 & 7.3 \\
disposal & & \\
All others & 136,161 & 27.5 \\
Debt service & 226,614 & 45.8 \\
\hline Total & 494,347 & 100.0 \\
\hline
\end{tabular}

Bonds (Capital) Fund, and payment by customers for the service, which covers repayment of principal and interest on loans. Sewer use charges are generally based upon metered water use (WSSC, 2006). The average interest rate on the current outstanding debt was $4.59 \%$ as of $06 / 30 / 2005$. The WSSC conducts a bond sale and award the bonds to the lowest bidder (Personal communication, J.D. Noell, January 11, 2006).

\section{The Current Budget FY'06}

The capital budget is $\$ 265$ million and the operating budget is $\$ 494$ million (WSSC, 2006). Both are going to be financed through bonds and the receipts for providing water and sewer services to the customers. From Table 1, the debt service constitutes around 46 $\%$ of the operating budget for the Fiscal Year 2006. WSSC finances its projects mostly through bonds, and the debt service covers both the principal and the interest.

Table 2. Capital budget - allocations and sources.

\begin{tabular}{lrr}
\hline & (\$ millions) & (\%) \\
\hline Allocation: & & \\
Water supply & 112,678 & 425.0 \\
Sewage disposal & 117,776 & 44.5 \\
General construction & 34,365 & 13.0 \\
Total & 264,819 & 100.0 \\
Sources: & & \\
$\begin{array}{l}\text { Bonds and cash } \\
\text { Federal/State grants }\end{array}$ & 217,449 & 82.1 \\
$\begin{array}{l}\text { System development } \\
\text { charge/others }\end{array}$ & 2,500 & 1.0 \\
$\begin{array}{l}\text { Paid house connections } \\
\text { revenue }\end{array}$ & 43,170 & 16.3 \\
\hline Total & 1,700 & 0.6 \\
\hline
\end{tabular}


The capital budget listed in Table 2 shows the allocation between water and sewage disposal projects in addition to the general construction. The lower part of Table 2 shows that $82 \%$ of the budget is to be financed through bonds and cash. Bonds issuance is more favorable and feasible than straight loans. Bonds will generate more funds because a group of banks and investment houses are sharing in its syndication and spreading the risk. For investors, bonds are more attractive because the annual return is fixed for years and at maturity, in most cases, the investor will get back the original investment.

What is important to note is that the existing state laws require that the water consumption rates be sufficient to meet all the designated provisions (WSSC, 2006). The WSSC maintained the same rate for the FY 1999-2004, but increased its rate in 2005 by an average of $2.5 \%$ for water and sewer rates.

Other sample cases, from the States of New York, Arkansas and Utah, will be presented to reflect diverse geographic locations.

Four small towns in the State of New York are receiving a low-interest loan for a regional water project. If the four towns agree to go ahead with the project, the New York Environmental Facilities Corp may be able to provide financing through a 30 -year loan. The first 20 years could be financed at $2 \%$ and the last 10 years at a fixed market rate, currently $5 \%$. The cost of the project is pegged at $\$ 24.8$ million (Glynn, 2005). In this case the state will be providing concessionary loans to water provider utility.

While the above case is a direct loan, in the State of Arkansas, a more interesting option was provided. The State was considering a loan of $\$ 88$ million to White River Regional Irrigation District (WRID) in order to finance a water project. The money will be used to design and build a system to take more than 1 billion gallons of water daily from the White River and deliver it to some 900 farms. The point is that if WRID was unable to pay back the loan with the interest, the general public in Arkansas would be responsible to pay, which caused dissention in the State. The governor still has to approve the bonds (Mays and Carruth, 2005). This case shows the interest of the state in helping out a number of farmers with the understanding that, in case of need, the general public will be paying for the cost. This example illustrates the state's interest in financing water projects, including non-urban projects. Further, the message is that the burden of debt repayment rests with all the taxpayers in the state and not the federal government.

The case of Utah deserves attention because it proposes another form of financing. Like all Western states, Utah finances much of its water infrastructure through the general fund and from sales tax. The sales tax proposal has been put forth by another task force studying how to pay for a project (Baired, 2005). The case here emphasizes the need for local beneficiaries to contribute and match the state funding -a concept which establishes equity and fairness within the state. The proposal, which was still pending as of January 2006, proposes lifting the sales tax cap on money appropriated for water projects, another bill proposes using a portion of future general fund surpluses. At this point, fiscal conservatives have been critical of both bills and environmentalists question the need for the Bear River project (Personal communication, J. Baired, January 11, 2006).

\section{The Federal Government}

The latest estimate showed that $\$ 500$ - $\$ 800$ billion is needed over the next 20 years for maintaining and improving the existing inventory, building new infrastructure, and meeting new water quality standards (Eichenscher, 2005). Therefore, U.S. Congress is concerned about the status of investment in the water sector. In support of the proposed bill, H.R. 1708, a seasoned water projects financier indicated that among other methods of financing, the tax exempt financing, is essential to ensure that local communities have the latitude to formulate financing strategies that can meet local needs and alleviate the financing burdens of federal mandates that local communities must comply with and ultimately pass on to the American ratepayer (Howard, 2005). The importance of the tax laws and its impact cannot be minimized and it really encourages investment initiatives.

Therefore, Congress approved the said Bill, which became known as the Clean Water Investment and Infrastructure Security Act of 2005, to finance water quality infrastructure projects. The main premise of this Act is to modify the Federal Tax Law to make the issuance of tax-exempt bonds for water and sewerage facilities, known as exempt facility bonds or private activity bonds (PABs), exempted from the volume cap, which limited its issuance above a certain amount per year by each state. These changes made the issuance of bonds more attractive to investors. 
The Act is expected to improve the financing of water projects across the country. Further, Congress enacted the Water for the Poor Act of 2005, which was submitted as House of R-epresentatives 1973. The Act is designed to make access to safe water and sanitation for developing countries a specific policy objective of the United States foreign assistance programs (Simon, 2005).

Financing options for new infrastructure projects can therefore be grouped as follows; each has its attraction to different investors. In a sense, investors, both private and corporate, are going to decide which investment option they are going to select based on many factors, one of which is the impact of such investment on their portfolio and the return after taxes.

1. Debt - tax-exempt bonds, governmental purpose bonds, private activity bonds

2. Equity - private equity, taxable bonds, tax-exempt private activity

\section{Some Water Sector Aspects in the Sultanate of Oman}

\section{Basic data}

The capital of Oman is Muscat, with other major cities being Salalah, Nizwa, Sohar and Sur. Its population according to official statistics is 2.4 million (Ministry of National Economy, 2004). Oman has 920,000 in the work force, $50 \%$ of whom are involved in agriculture and fishing (US Dept of State, 2006). The agriculture and fisheries sector contributes $2.1 \%$ to the total GDP. Oman's GDP-purchasing power parity in 2004 is estimated at $\$ 38.09$ billion or $\$ 13,100$ per capita GDPpurchasing power parity.

About $55 \%$ of the population lives in Muscat and the Batinah coastal plain northwest of the capital (Ministry of National Economy, 2004). Water resources, as in most Economic and Social Commission for Western Asia (ESCWA) countries, are owned by the State, which is responsible for conserving them and ensuring that they are used judiciously. Sector budget reflects the requirements of the following agencies: Ministry of Housing, Electricity and Water (MHEW), Ministry of Regional Municipalities, Environment and Water Resources (MRMEWR) and Governorate of Dhofar and Sohar Municipality. It is worth noting that the Water Law of 2000 consolidated the responsibility for all water resources within one ministry, with the exception of desalinated water (ESCWA, 2003).
The development, operation, maintenance and transmission of potable and desalinated water supplies are under the jurisdiction of MHEW. The distribution of potable water is under the jurisdiction of the MHEW, with the exception of Muscat, where it is under the jurisdiction of the Governorate of Muscat. The responsibility for the assessment and collection of tariffs for potable water supplies lies with the MHEW (ESCWA, 2004).

\section{Water sector and its financing}

Like in other developmental projects in Oman, all water resources planning and infrastructure development is controlled by the Ministry of National Economy (MNE). Water resources planning are set out in a 20-year National Water Resources Master Plan which is being implemented in 5-year stages under the jurisdiction of the MRMEWR and the MNE (World Bank, 2005).

The government's development plan gives priority to meeting demand for water from the domestic and industrial sectors. In the 2000-2005 Development Plan, the allocation was about R.O. 202 million (\$525 million) to that end (MNE, 2003). Oman relies on a variety of strategies, including greater reliance on desalination and water from shallow aquifers (ESCWA, 2004), among others to make better use of its available resources. With the emphasis on desalination, long term policy in the urban water sector aims at the partial or full privatization of the production of desalinated water and wastewater treatment (World Bank, 2005).

Developmental plans are financed from the State's revenue and borrowing both internally and from the international markets. The Omani Government has implemented its Sixth 5-year plan, launched in 2001, to reduce its dependence on oil and expatriate labor. The plan focused on income diversification and job creation for Omanis in the private sector. Currently, efforts are underway to liberalize investment opportunities in order to attract foreign capital (US Fed, 2005). This will have a direct impact on many economic sectors, including the water sector. For the Seventh 5-year plan (2006-2010), an estimated R.O. 20,896 million (\$54,346 million) was approved, with a deficit of R.O. 2,266 million (\$5,893 million). This deficit will be financed through borrowing and withdrawal from reserves. Oman obtains developmental loans from regional and international lenders, such as the Arab Fund and the Islamic Development Bank. One of the 
Plan's emphases is on enhancing the water resources and provision of safe water.

\section{Who pays for the water?}

In accordance with the State plans, a mega wastewater project for the capital city of Muscat, at a cost of $\$ 1$ billion, is being considered, with the government planning to undertake the entire financing. The proposed project will be a joint venture with an international firm. This complex project will create a wastewater system by 2025 that will treat about $200,000 \mathrm{~m}^{3}$ of water daily for reuse, covering $80 \%$ of the population by 2014 and $90 \%$ of the population by 2017. Wastewater will be collected, processed, treated and re-distributed. The project involves several parties, such as the Oman Wastewater Services Company, the Muscat Municipality, a private operator, project contractors and others (MNE, 2003). The project is in progress. Stage 1 is under implementation while stages 2 and 3 are in the design and tendering stages (Personal written communication, Z. Al Sulaimani, January 11, 2006). Implementation of this project demonstrates the desire of the State to upgrade the sector and its willingness to go the joint venture route and provide for the involvement of the private sector. There is clearly an emerging interest in reducing the reliance on government funding and engaging the private sector. There are many positive aspects of this trend. There will be more funds available, more expansion will take place and more people will be connected to the distribution network. The State will allocate its budget to more needy sectors. Above all, the proper management of water resources will be enhanced through the recognition of its value by the consumers.

\section{A plan in motion: new mega water project}

In accordance with the State plans, a mega wastewater project for the capital city of Muscat, at a cost of $\$ 1$ billion, is being considered, with the government planning to undertake the entire financing. The proposed project will be a joint venture with an international firm. This complex project will create a wastewater system by 2025 that will treat about $200,000 \mathrm{~m} 3$ of water daily for reuse, covering $80 \%$ of the population by 2014 and $90 \%$ of the population by 2017. Wastewater will be collected, processed, treated and re-distributed. The project involves several parties, such as the Oman Wastewater Services Company, the Muscat Municipality, a private operator, project contractors and others (MNE, 2003). The project is in progress. Stage 1 is under implementation while stages 2 and 3 are in the design and tendering stages (Personal written communication, Z. Al Sulaimani, January 11, 2006). Implementation of this project demonstrates the desire of the State to upgrade the sector and its willingness to go the joint venture route and provide for the involvement of the private sector. There is clearly an emerging interest in reducing the reliance on government funding and engaging the private sector. There are many positive aspects of this trend. There will be more funds available, more expansion will take place and more people will be connected to the distribution network. The State will allocate its budget to more needy sectors. Above all, the proper management of water resources will be enhanced through the recognition of its value by the consumers.

\section{Possibilities of Implementing Some U.S. Financing Methods}

\section{Obstacles in water project financing}

Based on the available options, some of the methods used in financing water projects in the U.S. could be considered for implementation in Oman. The transition could take time in order to lay the grounds for its success. The Tax Code in the U.S. provides a major impetus for investment opportunities. There is no personal income tax and only corporate income tax in Oman, thus there is no special attraction to private investors to purchase bonds. A combination of debt and equity could be used to promote the concept that users of water should pay, ultimately, the full cost of this benefit. When the financial obligations of the provider are determined by taking into consideration the interest of both the stakeholders and the creditors, then a proper tariff will be established to achieve these financial goals. Also, there will be positive attempts to control the expenses.

In order to have more chance of financing programs, certain issues need to be assessed and mitigated and they are related to financing water projects in general:

- High initial investment and long payback period

- Low rate of return

- Foreign exchange risk

- Sub-sovereign risk

- Risk of political pressure

- Contractual risk

The above are some issues to wrestle with. Country (sovereign) risk is also present as a general 
constraint in international finance and not limited to the water sector. Very few emerging markets have investment ratings that enable them to raise funds on attractive terms. Water projects have the additional disadvantage that there is a high minimum size of project finance, due to the size of legal costs and the terms for water projects. International project finance has large returns to scale because of the legal, financial and due diligence costs associated with it. Many water projects may not be viable for project finance because they fall below the minimum size for it. For the above reasons, international loans and equity investment in water have been low and falling. Banks and private companies are now more aware than ever of the risk-reward tradeoff (Camdessus, 2005).

\section{Brief Survey of the Gulf Cooperation Council Countries}

Before suggesting the possible actions in Oman, a brief review of the financing mechanism in the rest of the GCC countries will be presented.

The financing of infrastructure projects in general, and water projects in particular, is common among all of the GCC countries. The reliance on government funding is well understood. There are many reasons for such reliance. It is accepted that the State is responsible for those activities. In the meantime, the availability of funds allowed the states to meet the requirements within the boundaries of the annual state budget. Progress was made in providing residents of those countries with water at highly subsidized prices. The latest report of the World Bank showed clearly that the burden is becoming enormous. The cost of subsidies in Bahrain was around \$55 million, which represents $0.7 \%$ of GDP and $1.4 \%$ of oil export revenue. The subsidies in Saudi Arabia represent around \$3,175 million, $1.7 \%$ of GDP and 7\% of oil export revenue. Oman's subsidies are the lowest among the GCC at $\$ 85$ million and $0.4 \%$ of GDP and $1.1 \%$ of oil export revenue (World Bank, 2005). With the increase in population and the need to have more facilities, the burden is going to be horrendous. The trend towards privatization is progressing with emphasis on new projects, such as the Sulaibiya Wastewater Plant in Kuwait, the Taweelah A2 in United Arab Emirates and the Desalination Company of Ras Laffan (ESCWA, 2003) in Qatar. One of the major undertakings is in Saudi Arabia where the government is looking for
Independent Water and Power Producers (IWPPs) to provide a large proportion of new generating electric capacity and drinking water; the initial plan calls for four IWPPs, and each is expected to cost $\$ 1$ billion. The government hopes to offer a 60 percent stake in each of the four projects to private companies. It is clear that the trend is moving towards engaging the private sector in the ownership and the management of the water facilities, and less reliance is being placed on the government.

\section{Oman's Possible Actions}

Financing the water sector should be examined thoroughly and a proper course(s) of action should be advanced and presented to the decision makers. In order to have more financing options, it is necessary to restructure government agencies and make them autonomous entities. Then, along with other private providers, they could try to form an association and strive to get a credit rating as well. After assembling the proper ingredients for possible success, water service providers should focus on the most important element of having a tariff which should cover initially all the operating costs and ultimately reach full cost recovery.

In the case of Oman, subsidies should be transparent and reviewed continuously to ensure they target the intended beneficiaries. Oman is moving towards a reduction in its subsidies programs (World Bank, 2005). This is a good sign. Still, subsidy should be provided on the basis of need. Such assessment should be implemented in the short term and without delay.

After assessing the sectoral requirements and taking the decision to have an equitable tariff, which is supposed to provide for cost recovery and the financing of new projects, a financing model could be identified. Water providers could borrow from the local, the GCC or the international markets. Anchor investors, like the pension fund and others in Oman, could facilitate the process. The banking system in Oman remains strong, with proper supervision and with sound lending practices, and in a healthy economy asset prices continued to strengthen. The Muscat Securities Market index gained $24 \%$ in 2004 and surged another $60 \%$ in the first half of 2005 (Ford, 2005). Banks are making solid profits and continue to grow, both in terms of corporate and personal lending 
(GCC, 2005). These indicators should provide good possibilities for borrowing locally.

Oman is proceeding to have its newest independent private water project with international investors. Four Japanese conglomerates are considering Oman's first independent water project, being developed in the Sharqiyah region. Marubeni Corp, Mitsui \& Company, Sojitz Corp and Sumitomo Corp are among fifteen international companies so far expressing interest. The multi-million dollar project is expected to have a desalination capacity of $15-20$ million gallons per day (AME, 2005) and is in the tendering stage.

While it is premature to assess its impact on tariffs and other factors, it is clear that investors are interested in getting a market rate return on their investment. That could be achieved through a proper tariff structure. However, the actual tariff structure may be below the envisioned ones due to its negative impact on the customers. In this case, the state may provide certain incentives, subsidies, and other rewards in order to meet the expectations of the investors. The issue of security safeguards should be assessed and promoted. The security of infrastructure projects in general, and water projects in particular, should be assessed and monitored. In the case of privatized operations, the state should have direct control over that function and should be compensated for it.

\section{Conclusions and Recommendations}

Population growth and the decrease in the availability of water is a worldwide phenomenon. Aside from the need for building new facilities, there is a need for upgrading and rehabilitating the existing facilities. The cost is in billions of dollars. The reliance on government budgets is going to limit the implementation of such needed tasks. There is an urgent need for proper financial engineering to implement projects and not to burden and choke government budgets.

The experience of the Washington Suburban and Sanitary Commission in the Maryland suburb was used as a case in point, having an independent public agency taking care of 1.6 million people with proper self financing and without burdening the tax payers in the State. Other cases were cited from the States of New York, Arkansas and Utah. These reduce to the simple premise that users should pay for the cost of having safe water. The ultimate tariff structure should cover the operating and capital cost. With proper administration the goal could be achieved.

In Oman, while the trend of privatization is advancing rapidly, especially in the desalination and wastewater areas, the implementation of some of the methods used in the U.S. are possible, namely,

- Allowing private equity participation in the operation of the water facilities, with the understanding that a suitable form of privatization is possible after a certain period. Water providers could rely on borrowing, either through direct loans or through the flotation of bonds.

- Assessing the possibility of imposing a sales tax on certain luxury products, such as cars and jewelry, could be considered.

- Encouraging the banking system and anchor investors, such as the Social Security Pension Fund, to lead the way in making funds available to finance water projects. This is part of a proper investment strategy by which investment should be diversified to mitigate the risk.

- Phasing out subsidies gradually but maintaining this for the economically disadvantaged.

- Reducing the agricultural usage of water resources, through the mechanism of implementing block rates and limiting access to that resource, and encouraging the growing of agricultural products that require less water to grow.

- Maintaining a tariff structure which will ultimately cover all the operating and capital needs of the service provider in question. With sound financial planning, there will be equity in the water charges and that will provide financial stability to the service providers, which in turn, will enable them to serve more people and eventually reduce the final cost due to the economy of scale.

\section{Acknowledgements}

I would like to thank Zaher Al Sulaimani, Slim Zekri, Sheila Cohen, Muwaffaq Saqqar, Mowafak Al Yafi and Kareem Nakshbendi for their valuable critique. Also to Joe Baired and J.D. Noell for their timely update of data and to the University of Maryland 
University College Library for its continued support and assistance.

\section{References}

AME. 2005. Japanese on Oman Water. AME Info - ME Energy, August 28, 2005.

Baired, J. 2005. Sales tax financing for water projects debated. Salt Lake Tribune (Utah), August 12, 2005. Retrieved 12/27/2005 from Lexis Nexis.

Business and Industry. 2005. Oman to sell 30\% stake in Omantel. Business and Industry, Telecomworldwire, April 14, 2005. Retrieved 12/ 23/2005 from Lexis Nexis.

Camdessus. 2005. Financing Water for All. Report of the World Panel on Financing Water Infrastructure, World Water Council, 3rd World Water Forum Globak Water Partnership. http://ww w.worldwatercouncil.org/fileadmin/wwc/Library/ Publications.and reports/CamdessusReport.pdf. p.5. Retrieved 12/27/2005.

Eichenscher, T. 2005. Budget cuts could spur privatepublic partnerships. Natural Resources, 10:9, July 25, 2005. Retrieved 11/25/2005 from Lexis Nexis.

ESCWA, 2003. Assessment of the Role of the Private Sector in the Development and Management of Water Supply in Selected ESCWA Member Countries, ESCWA, October 3, 2003. p 31.

ESCWA. 2004. The Optimization of Water Resources Management in the ESCWA Countries: A Survey of Measures taken by the ESCWA Countries during the 1990s for the Optimization of Water Resources Management and Capacity-building in the Water Sector, New York, U.N. 2004. http.// www.escwa.org.lb/information/Publications/edit/

Ford, N. 2005. Waiting for Privatization. Middle East, Jan 2005 Issue 352, pp. 38-39.

GCC. 2005. Oman Attracts Regional Interest. In: The Banker, August 1, 2005.

Glynn, M. 2005. Low-interest loan eyed for water system. The Buffalo News, January 3, 2005. Retrieved 11/15/2005 from Lexis Nexis.
Howard, S. 2005. Financing water infrastructure projects. Federal Document Clearing House Congressional Testimony, June 14, 2005.

IMF. 2005. Executive Board Concludes 2005 Article IV Consultation with Oman, December 9, 2005, IMF. Retrieved 12/29/05. http://www.imf.org/ external/np/sec/pn2005/pn05165.htm.

Mays, R.H. and D. Carruth. 2005. Tax dollars used to help 900 farmers irrigate crops. Arkansas Democrat-Gazette, 2005.

Ministry of National Economy. 2004. General Census for Population, Housing and Establishments. http: //www.omancensus.net/english/inde.asp.

MNE. 2003. The Sixth Five Year Development Plan 2001-2005. Ministry of National Economy, Sultanate of Oman.

Simon, P. 2005. Water for the Poor Act of 2005. Passed the House of Representatives on November 7, 2005. 109th Congress, 1st Session in the House of Representatives as introduced in the House, April 19, 2005. Retrieved 12/15/2005 from Lexis Nexis.

United Nations 2005. Millennium Declaration. Resolution adopted by the General Assembly [(A/55/L.2)] 55/2. http://www.un.org/millennium/ declaration/ares552e.htm. (12/13/2005).

US Dept of State. 2006. Background Note: Oman. www.satet.gov/r/pa/ei/bgn/35834.htm.

US Fed. 2005. State Department Issues Background Note on Oman. US Fed News February 1, 2005.

World Bank. 2005 A Water Sector Assessment Report on the Countries of the Cooperation Council of the Arab States of the Gulf. March 31. 2005.

WWSC. 2006. Approved Budget Fiscal Year 20006, July 1, 2005. Retrieved 12/27/2005, from Lexis Nexis. http://www.wsscwater.com/budget. FY06. pdf p. 15.

Zeilig, N. 2005. Bridge Over troubled Water. American City \& County, June 2005. http://ww w.americancityandcounty.com/mag/government bridge_troubled_water/ 